\title{
INCREMENTAL DYNAMIC ANALYSIS OF MID-RISE RC BUILDINGS TO ASSESS EFFECT OF CONCRETE STRENGTH AND TENSION REINFORCEMENT RATIO IN BEAM
}

Onur ONAT

Burak YÖN"

Received: 25.11.2020; revised: 15.12.2020; accepted: 07.02.2021

\begin{abstract}
IDA is a parametric analysis method that has used commonly in several different forms to assess the structural performance under seismic loadings. This paper focuses on the effect of tension reinforcement ratio and concrete strength to performance of reinforced concrete (RC) structures. For numerical analysis, two RC frame type structures were selected. One of them is 5 stories other of them is 7 stories. Two different concrete class, C20 and C25, were considered and three tension reinforcement ratios were considered for analyses. Tension reinforcement ratios were determined half of the compressive reinforcement, equal to compressive reinforcement and double of compressive reinforcement ratio. Incremental dynamic analyses (IDA) were performed on these buildings. In this study to execute IDA, eleven seismic acceleration benchmark records were multiplied with various scaling factors from 0.2 to 1.2. Maximum base shear and corresponding roof displacement responses obtained from IDA curves were generated according to these responses. IDA curves were compared with each other by using suitable graphs. According to analyses results, increasing tension reinforcement of beam elements has not any effect on maximum roof displacement. Whereas, increasing of tension reinforcement decreased interstorey drift ratio. This result limited the damage due to decreased interstorey drift ratio.
\end{abstract}

Keywords: Incremental Dynamic Analysis, Reinforced Concrete Structures, Tension Reinforcement, Concrete Class

\section{Beton Dayanımının ve Kirişlerdeki Çekme Donatısı Oranının Orta Yükseklikli Betonarme Binaların Sismik Davranışı Üzerine Etkisinin Belirlenmesi için Artımsal Dinamik Analiz}

Öz: Artımsal Dinamik Analiz (ADA), sismik yükler altında yapısal performansı değerlendirmek için birkaç farklı biçimde yaygın olarak kullanılan parametrik bir sonuç analizi yöntemidir. Bu yöntem, seçilmiş olan bir grup sismik kayıtın ölçeklenerek yapısal sisteme etki ettirilerek, bu etki altında, elastik tepkiden genel dinamik yapısal stabiliteye ulaşmayı öneren bir analiz türüdür. Bu çalışmada çekme donatısı oranı ve beton dayanımının orta yükseklikli betonarme yapıların sismik davranışı üzerine etkisi incelenmiştir. Sayısal çalışma olarak 5 açıklıklı, 5 ve 7 katlı iki farklı sayısal model oluşturulmuştur. Her bir model için üç farklı çekme donatısı oranı ve iki farklı beton sınıfı seçilmiştir. Çekme donatısı oranları, basınç bölgesindeki donatının yarısı, bir katı ve iki katı olarak belirlenmiştir. Sayısal modeller artımsal dinamik yük altında analiz edilmiştir. Bu analiz için on bir farklı sismik kayıt kullanılmıştır. Bu kayıtlar 0.2g'den 1.2g'ye kadar 0.2g artımlar ile ölçeklenmiştir. Yapılan artımsal dinamik analizler sonucunda yapısal sistemlerin taban kesme kuvvetleri ve karşılık gelen çatı

\footnotetext{
* Inonu University, Engineering Faculty, Department of Civil Engineering, 44280, Malatya, TURKEY

** Munzur University, Engineering Faculty, Department of Civil Engineering, 62000, Tunceli, TURKEY

Corresponding Author: Onur ONAT (onur.onat@inonu.edu.tr)
} 
Onat O., Yön B.: Incremental Dynamc. Analysis of Mid-Rise RC Buildings

katı deplasmanları karşılaştııılmıştır. Elde edilen analiz sonuçlarına göre kirişlerde çekme donatısı oranını arttırmak çatı katı deplasmanını düşürmese de katlar arası göreli ötelenmeyi azaltmıştır, böylelikle hasar seviyesini azaltacağı için hasar oranını düşürmektedir.

Anahtar Kelimeler: Artımsal Dinamik Analiz, Çekme Donatısı, Beton Sınıfı, Betonarme Yapı

\section{INTRODUCTION}

Dynamic Analysis is a kind of analysis method performed to assess actual structural behavior a finely modelled structural system by using seismic records. The basic idea is to determine the performance levels of structural systems. In this analysis, uncertainties are less than other analysis methods. As a result of the analyzes performed with this analysis method, the nonlinear behavior of each element and the complete structural system that constitutes the structural system is determined in accordance with each degree of freedom (Karabulut 2011; Yön 2016). The basic idea of the performance-based earthquake engineering is the estimation of structural performance under seismic loads, especially the frequency of exceeding the specified structural demand. Structural systems show different response under different seismic records. Difficult to predict which of these seismic actions generate the critical effect on the structural system without analysis. For this philosophy, the Incremental Dynamic Analysis (IDA) method has been developed (Vamvatsikos and Cornell 2002; Vamvatsikos and Cornell 2004; Yön and Calayır 2015). After proposed, this method was performed successfully for versatile purpose. Moreover, this method provides rapid and practical solution to assess any type of structural system for nonlinear simulation. In addition, using this method save huge budgets in order not to perform shake table experiments as reported in the literature (Onat et al. 2015, Onat et al. 2016). Because the possible challenge during these experiments is to face with problem related to incomplete boundary condition (Onat et al. 2017) and missing data due to device removal (Onat and Yön 2019; Onat 2019). Reported in the literature that conducted studies with this method presents satisfactory results in terms of different aims. In this context, structural response or element behavior that constituted with any defect can only be revealed through IDA analyzes that can be performed correctly. These defects can be reinforcement corrosion (Fantilli et al. 1999), tension reinforcement at high strength beam (Ashour 2000), concrete confinement (Lee and Pan 2003), low concrete strength due to missing quality control (Rizwan et al. 2020), Chloride induced corrosion of RC frame (Kordtabar and Dehestani 2020) and local seismic effect (Yön et al. 2014). The common side of the listed studies above are on RC structures, constant axis interval, defect effect on the performance of low or medium rise RC frame commonly used in the literature (Martineau et al. 2020, Wu et al. 2020). In detail, listed studies above present that tension or compression reinforcement ratio may change due to external effects such as corrosion and deterioration of rebars as reported by Theriaule and Benmokrane (1998). It was reported that two important parameters have influenced on performance of bar ratio change. One of them is propagated as crack width, other of them is crack spacing. These two factors are restricted with tension reinforcement ratio. Fantilli et al. (1999) investigated tension reinforcement ratio on structural performance on the base of bond-slip behavior. Minimum steel bar ratio is affected by the bar diameter. Thus, bond slip behavior is profoundly affected by the bar diameter. Ashour (2000) experimentally investigated tension reinforcement ratio on the high-strength beam behavior. Increasing compressive strength allowed beam to behave more flexible. Lee and Pan (2003) investigated concrete confinement and spalling of concrete on the base of tension rebar ratio. Lee and Pan draw attention to fulfill ductility of structural members during design phase. Yön et al. (2014) investigated site conditions and effects of seismic zones on RC structures by using IDA. Onat et al. (2016) performed IDA with artificially produced earthquake on 
the base of Eurocode 8. Their paper aims to investigate global behavior of infill wall on complete structure. Onat et al. (2018a) investigated performance of RC structures with shear wall by using IDA. Onat et al. (2018b) performed IDA to compare RC structures before and after retrofitting.

In this paper, it is aimed to investigate the effect of concrete compressive strength and tension reinforcement ratio of beam on ductility and capacity of RC structures. For this purpose, two RC structure were selected. One of them is composed of 5 stories and other of them is composed of 7 stories. Two different concrete compressive strength were considered. Eleven seismic records were used to perform IDA. The basic motivation is to determine physical dimension, floor height and reinforcement ratio are listed studies in the literature (Mawafy and Khalifa 2017, Nazari and Saatçioğlu 2017, Rizwan et al. 2020, Kordtabar and Dehestani 2020, Martineau et al. 2020, Wu et al. 2020, Yön 2020)

\section{NUMERIC MODEL AND METHOD}

Both model in this study were defined with fiber element model which accounts plasticity. This plasticity is spread through to the cross-section and the length of the element. In this hinge model, the structural element is divided in three types of fibers: one type fibers are used for modelling of longitudinal steel reinforcing rods; second type of fibers are used to define nonlinear behavior of confined concrete which consists of core concrete; and third type fibers are defined for unconfined concrete which includes cover concrete. Also, the stress/strain diagram is determined for the nonlinearity by using constitutive laws for each fiber element like rebar, confined concrete and cover concrete, according to defined materials. Figure 1 shows typical fiber modelling for a rectangular reinforced concrete section.
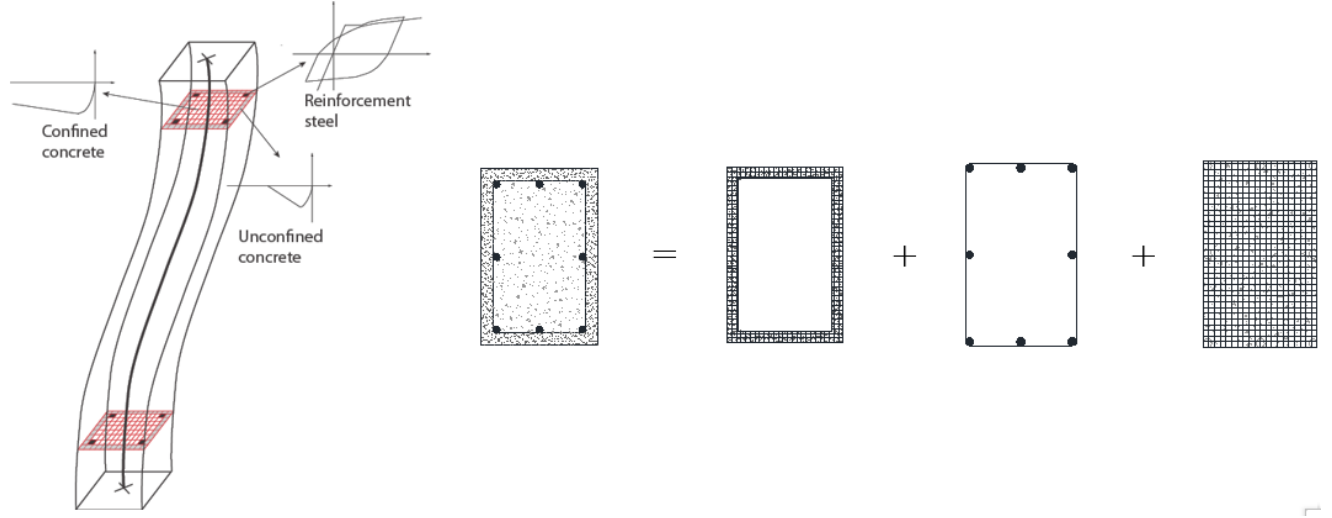

Typical fiber model of a RC element (Rodrigues, 2012)

\subsection{Description of Numeric Model}

Numeric models were genrated with 5 storeys and 7 storeys RC frame. Both of the RC frames have 5 bays and width of the bay is $5 \mathrm{~m}$. Two different concrete compressive strength were considered C20 and C25. Indeed, current and fore date Turkish seismic codes do not allow to be used lower concrete strength than $25 \mathrm{MPa}$. However, the basic idea is to select $20 \mathrm{MPa}$ concrete compressive strength is to simulate compressive strength degradation due to missing quality control of concrete at site. Moreover, yield strength of rebar was considered as $420 \mathrm{MPa}$. Five story generic model, cross 
sections of columns, beam and steel rebar orientations are presented in Figure 2. Floor to floor height is $3.0 \mathrm{~m}$ and this value is constant for both models. The dimensions of the columns were selected as $40 \mathrm{~cm} / 40 \mathrm{~cm}$ for 5 story building and $50 \mathrm{~cm} / 50 \mathrm{~cm}$ for 7 story building. Moreover, dimensions of the beams were selected as 25/50 for both of the models. The nonlinear incremental dynamic analyses were performed on the buildings as indicated in Turkish Building Earthquake Code (TBEC) (2018). The building importance coefficient is assumed as 1.0 for the generated both of the buildings. Boundary condition of the buildings were supposed as fixed support. Also, the soil differences and damping coefficients in accordance with the soil were not considered. For IDA analyses, SeismoStruct (2014) program was used which is able to simulate the inelastic structural systems response. Four Gauss integration points were selected to calculate the element forces and the stressstrain relationship for each section. In this study, while generating the numeric models, the superimposed dead load and the live load were considered as defined in the Turkish Standard 498 (1987) for residence.

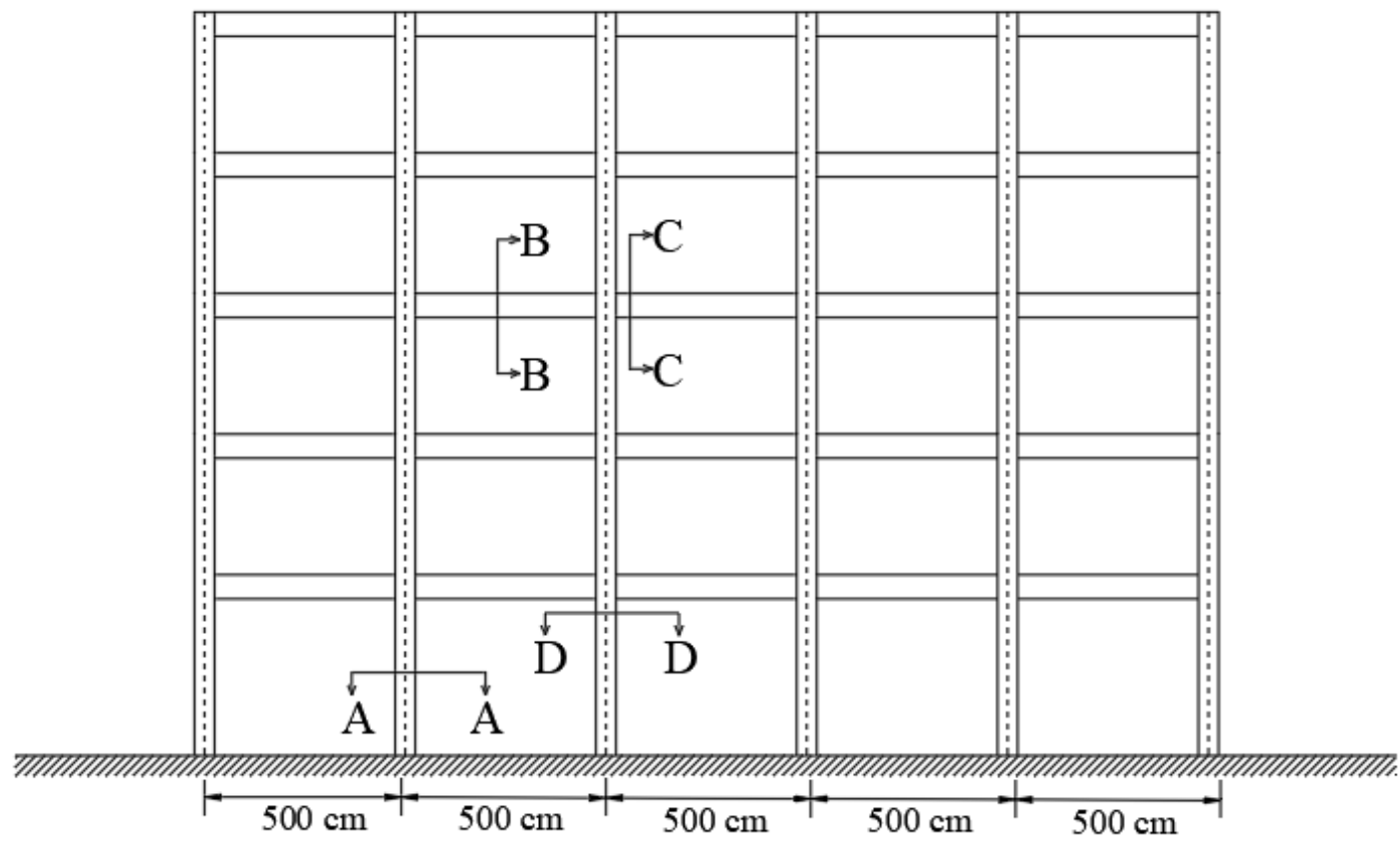

a) 

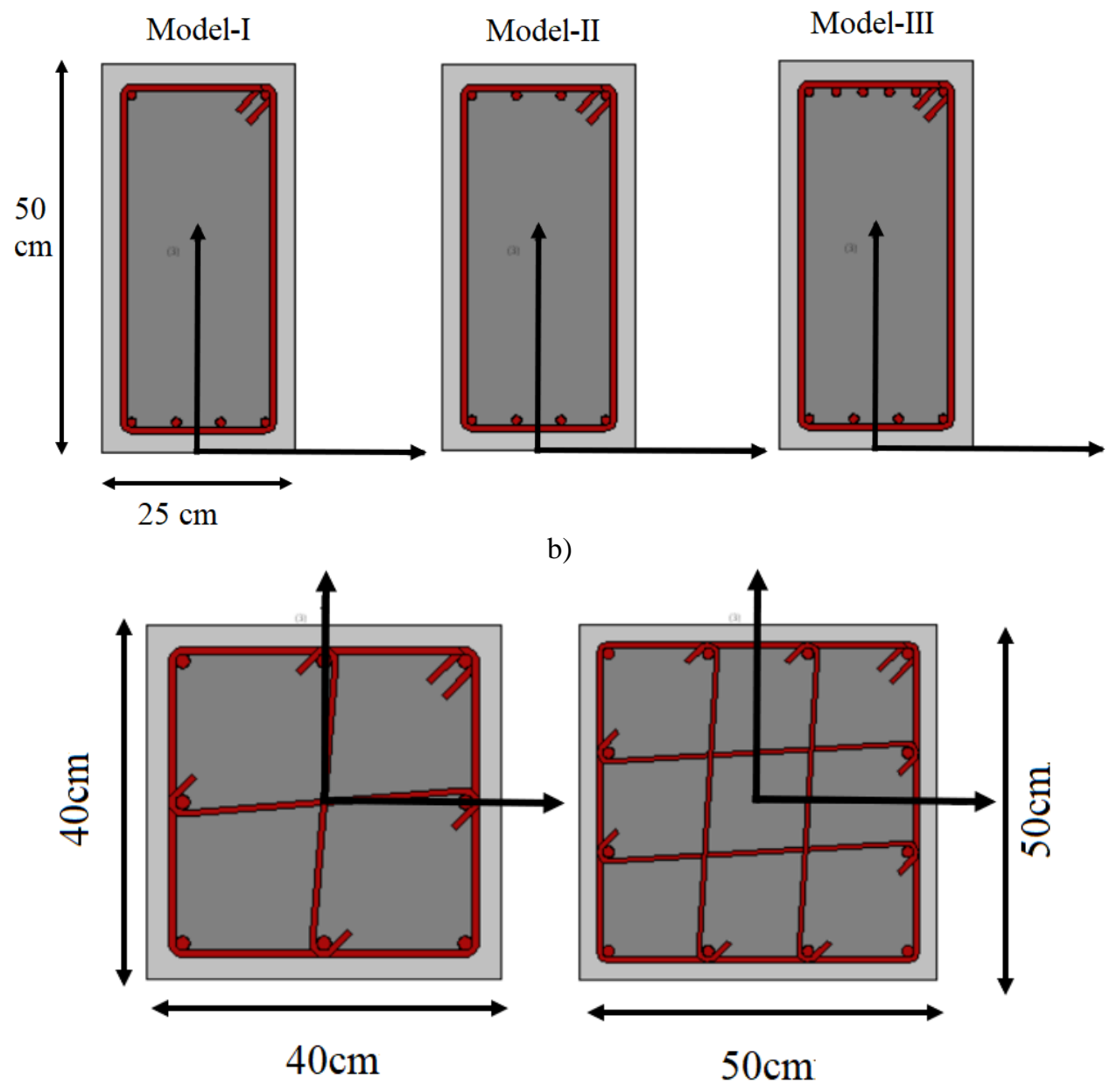

c)

Figure 2:

a. Generic 5 storey model, b. Cross sections

\subsection{Adopted Material Models, Properties and Seismic Records}

The bilinear elastic-plastic material model which includes kinematic strain hardening is used for the rebar. Concrete material is defined by the uniaxial confined concrete model (Figure 3) (Kwon and Kim 2007, Duan and Hueste 2012). The confinement effect is calculated by using Mander (1988) model. Reinforced concrete parameters related to structural elements are tabulated in Table 1. 
Onat O., Yön B.: Incremental Dynamc. Analysis of Mid-Rise RC Buildings

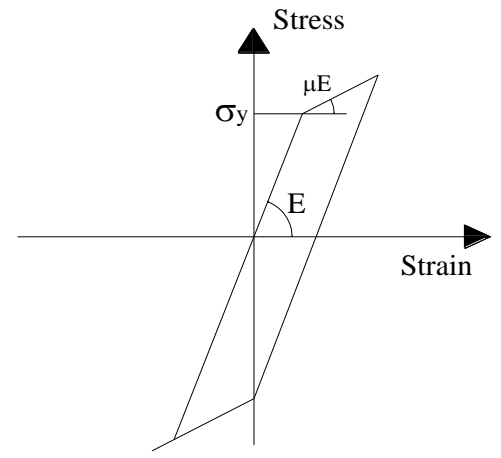

a) Reinforcing bar

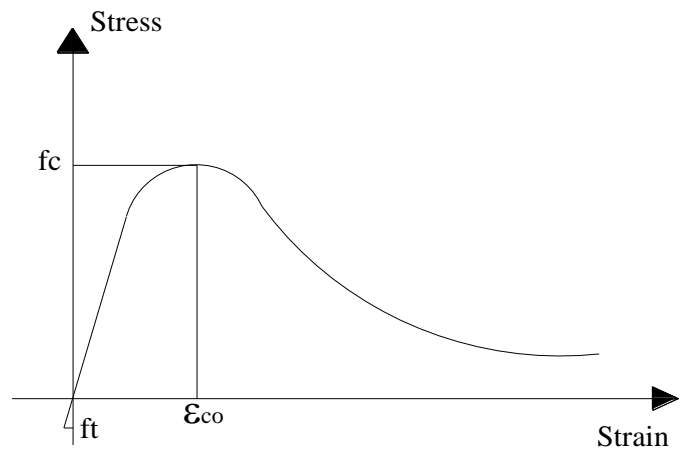

b) Concrete

Figure 3:

Material models for reinforcing bar and concrete

Table 1. Reinforced concrete parameters related to structural elements

\begin{tabular}{|c|c|c|c|c|}
\hline \multicolumn{2}{|c|}{ Structural Elements } & $\begin{array}{l}\text { Longitudinal } \\
\text { reinforcement }\end{array}$ & Section & $\begin{array}{l}\text { Transverse } \\
\text { reinforcement } \\
\text { spacing }(\mathrm{cm})\end{array}$ \\
\hline \multirow{2}{*}{$\begin{array}{l}\text { Column } \\
(50 / 50 \\
\text { and } \\
40 / 40)\end{array}$} & $\begin{array}{l}\text { Confinement } \\
\text { zone of } \\
\text { column }\end{array}$ & \multirow{2}{*}{$8 \varnothing 16$} & A-A & 15 \\
\hline & $\begin{array}{l}\text { Central zone } \\
\text { of column }\end{array}$ & & A-A & 15 \\
\hline $\begin{array}{c}\text { Column } \\
(50 / 50 \\
\text { and } \\
40 / 40)\end{array}$ & $\begin{array}{c}\text { Shear } \\
\text { Confined } \\
\text { Zone }\end{array}$ & $\varnothing 8$ & D-D & 7 \\
\hline \multirow{2}{*}{$\begin{array}{l}\text { Beam } \\
(25 / 50)\end{array}$} & $\begin{array}{l}\text { Confinement } \\
\text { zone of beam }\end{array}$ & $\begin{array}{c}\text { Top reinforcement } \\
4 \varnothing 12\end{array}$ & \multirow{2}{*}{ B-B } & \multirow{2}{*}{20} \\
\hline & $\begin{array}{l}\text { Central zone } \\
\text { of beam }\end{array}$ & $\begin{array}{c}\text { Bottom } \\
\text { reinforcement } \\
4 \varnothing 12\end{array}$ & & \\
\hline $\begin{array}{l}\text { Beam } \\
(25 / 50)\end{array}$ & $\begin{array}{l}\text { Shear } \\
\text { Confined } \\
\text { Zone }\end{array}$ & $\varnothing 8$ & $\mathrm{C}-\mathrm{C}$ & 10 \\
\hline
\end{tabular}

Model-I represents $\frac{\rho}{\rho^{\prime}}=\frac{1}{2}$, Model-II represents $\frac{\rho}{\rho^{\prime}}=1$, Model-III represents $\frac{\rho}{\rho^{\prime}}=\frac{3}{2}$. Where $\rho^{\prime}$ represents the rebar area of compression reinforcement, $\rho$ represents the rebar area of tension reinforcement in beam element. After constructing structural models, eigenvalue analysis was performed on the structures to determine mode shapes and frequencies and tabulated in Table 2 and 3. The idea of this analysis is to present the intensity measure parameters on numeric models with changing variations. 
Table 2. Eigenvalue analysis results for 5 storey $\mathrm{RC}$ model

\begin{tabular}{|c|c|c|c|c|c|c|}
\hline Mod Number & $\begin{array}{c}\text { MI C20 } \\
(\mathbf{H z})\end{array}$ & $\begin{array}{c}\text { MI C25 } \\
(\mathbf{H z})\end{array}$ & $\begin{array}{c}\text { MII 20 } \\
(\mathbf{H z})\end{array}$ & $\begin{array}{c}\text { MII 25 } \\
(\mathbf{H z})\end{array}$ & $\begin{array}{c}\text { MIII 20 } \\
(\mathbf{H z})\end{array}$ & $\begin{array}{c}\text { MIII C25 } \\
(\mathbf{H z})\end{array}$ \\
\hline 1 & 0.312 & 0.321 & 0.122 & 0.321 & 0.312 & 0.127 \\
\hline 2 & 0.576 & 0.592 & 0.234 & 0.592 & NA $^{*}$ & 0.237 \\
\hline 3 & 1.211 & 1.246 & 0.508 & 1.246 & NA $^{*}$ & 0.502 \\
\hline
\end{tabular}

*NA means Not Available; these modes could not be calculated.

After performing eigenvalue analysis, $90 \%$ participation was achieved at eighth mode. In Table 2, only three modes were considered for Model-I C20 and Model-I C25. As seen from Table 2, only first mode was calculated for Model-III with $20 \mathrm{MPa}$ concrete compressive strength.

Table 3. Eigenvalue analysis results for 7 storey $\mathrm{RC}$ model

\begin{tabular}{|c|c|c|c|c|c|c|}
\hline Mod Number & $\begin{array}{c}\text { MI C20 } \\
(\mathbf{H z})\end{array}$ & $\begin{array}{c}\text { MI C25 } \\
(\mathbf{H z})\end{array}$ & $\begin{array}{c}\text { MII 20 } \\
(\mathbf{H z})\end{array}$ & $\begin{array}{c}\text { MII 25 } \\
(\mathbf{H z})\end{array}$ & $\begin{array}{c}\text { MIII 20 } \\
(\mathbf{H z})\end{array}$ & $\begin{array}{c}\text { MIII C25 } \\
(\mathbf{H z})\end{array}$ \\
\hline 1 & 0.249 & 0.256 & 0.249 & 0.256 & 0.249 & 0.256 \\
\hline 2 & 0.538 & 0.554 & 0.538 & 0.554 & 0.538 & 0.554 \\
\hline 3 & 1.295 & 1.333 & 1.296 & 1.333 & 1.297 & 1.335 \\
\hline
\end{tabular}

As seen from Table 3, all modes were calculated for all models and concrete classes. Concrete class has no extensive impact on mode frequencies for 7 storey generic model.

Indeed, TBEC 2018 suggests performing IDA with eleven seismic record. Used records were presented in Figure 4 with Peak Ground Acceleration (PGA) values below. Six dynamic analysis were performed for each of the earthquake records from $0.2 \mathrm{~g}$ to $1.2 \mathrm{~g}$ with an increment step $0.2 \mathrm{~g}$ differences. Earthquake characteristics of used seismic records can be seen in Table 4.

Table 4. Selected earthquake acceleration records for dynamic analyses

\begin{tabular}{|c|c|c|c|c|c|c|}
\hline Number & Earthquakes & Station & Direction & Date & Magnitude & $\begin{array}{l}\text { PGA } \\
\text { (gal) }\end{array}$ \\
\hline 1 & Kocaeli & Düzce & E-W & August 17,1999 & 7.4 & 373.76 \\
\hline 2 & Kocaeli & Sakarya & E-W & August 17,1999 & 7.4 & 407.04 \\
\hline 3 & Düzce & Bolu & E-W & $\begin{array}{c}\text { November } 12, \\
1999\end{array}$ & 7.2 & 805.78 \\
\hline 4 & Düzce & Düzce & E-W & $\begin{array}{c}\text { November } 12, \\
1999\end{array}$ & 7.2 & 513.78 \\
\hline 5 & Van & $\begin{array}{c}\text { Van- } \\
\text { Muradiye }\end{array}$ & $\mathrm{N}-\mathrm{S}$ & October 23, 2011 & 6.7 & 178.5 \\
\hline 6 & Van & Van & E-W & $\begin{array}{c}\text { November } 9 \\
2011\end{array}$ & 5.6 & 245.9 \\
\hline 7 & Erzincan & Erzincan & E-W & March 13, 1992 & 6.1 & 470.91 \\
\hline
\end{tabular}


Onat O., Yön B.: Incremental Dynamc. Analysis of Mid-Rise RC Buildings

\begin{tabular}{|c|c|c|c|c|c|c|}
\hline 8 & Bingöl & Bingöl & N-S & May 1, 2003 & 6.1 & 545.53 \\
\hline 9 & Sultandağ1 & Afyon & N-S & February 3, 2002 & 6.1 & 113.5 \\
\hline 10 & Dinar & Afton-Dinar & E-W & October 1, 1995 & 6.0 & 329.72 \\
\hline 11 & Ceyhan & $\begin{array}{c}\text { Adana- } \\
\text { Ceyhan }\end{array}$ & E-W & June 27, 1998 & 5.9 & 273.55 \\
\hline
\end{tabular}

\section{RESULTS AND DISCUSSION}

The IDA results were plotted with different graphs. Response evaluation of numeric models were performed according to concrete story number of the numeric models. Response of 5 story numeric model with $20 \mathrm{MPa}$ concrete class can be seen in Figure 4.

According to IDA results, increasing tension reinforcement ratio provided additional lateral base shear demand. However, there are one exceptional situation for these analyses. Exceptional situation was observed at IDA with Erzincan record. The same reinforcement ratio of tension with equal to compression area decreased global lateral base shear demand. Then 50\% surplus tension reinforcement ratio than compression reinforcement ratio provided higher lateral base shear demand than equal situation. Response of 5 story numeric model with $25 \mathrm{MPa}$ concrete class was presented in Figure 5.

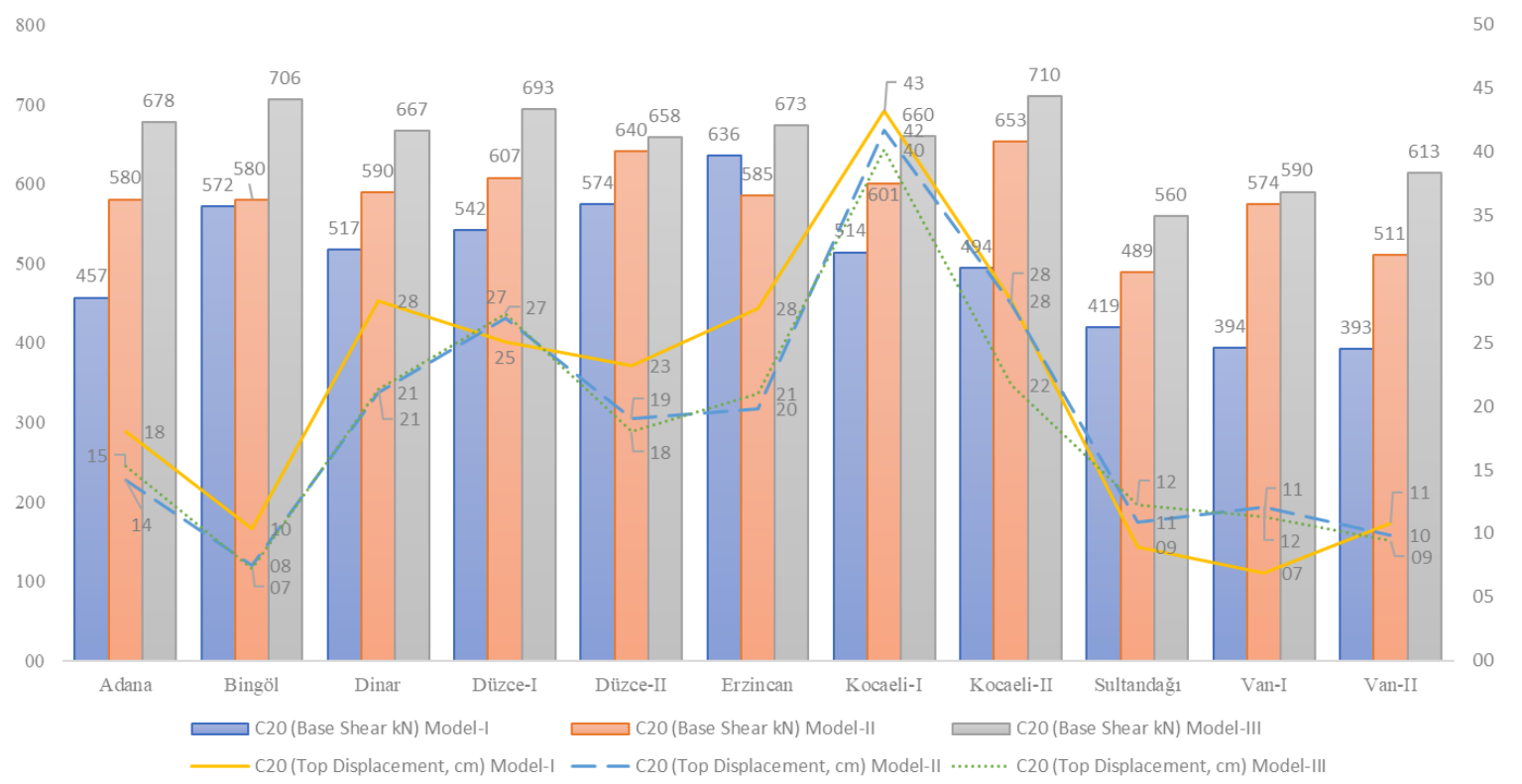

Figure 4:

Seismic response of the five-story generic numeric model with C20 concrete 


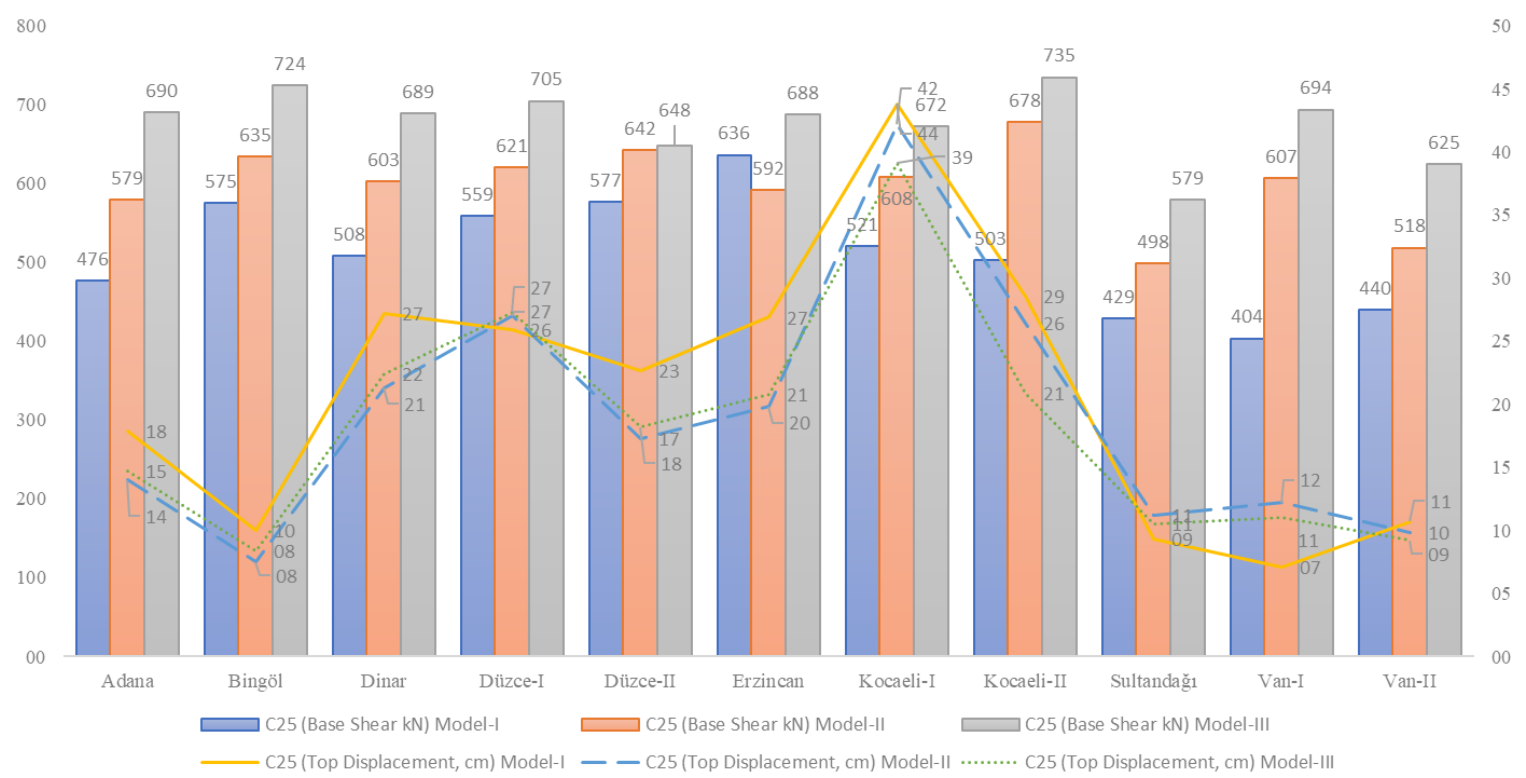

Figure 5:

Seismic response of the five-story generic numeric model with $C 25$ concrete

There is an increasing trend at base shear and top displacement with an increasing tension reinforcement ratio. However, one another exceptional situation was obtained at Erzincan record. Obtained maximum resistivity $734.8 \mathrm{kN}$ with Kocaeli-II record and minimum resistivity 579.4 $\mathrm{kN}$ with Sultandağı record.

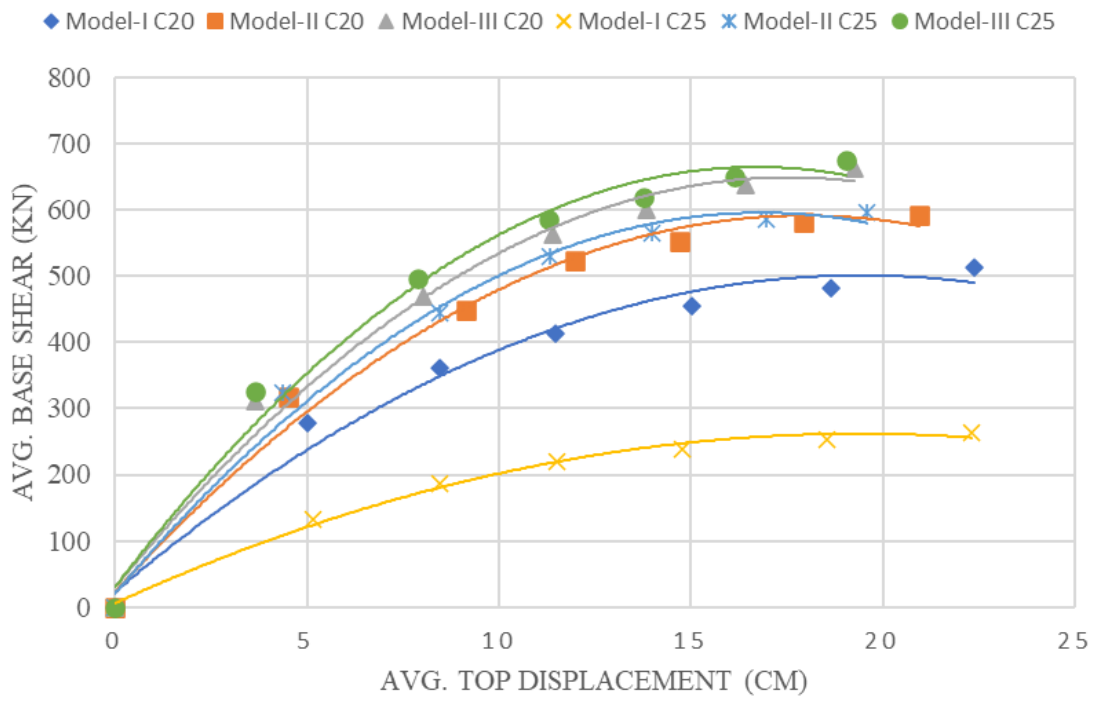

Figure 6:

Average IDA results for 5 story structure

During plotting Figure 6, average of all displacements and base shear forces were calculated at the same scale factor. The aim is to plot this curve is to see visual performance of the effect of tension 
reinforcement ratio and concrete class on the response of analyzed RC structure. As presented in Figure 6, at lower tension reinforcement ratio, lower concrete class revealed rather ductile behavior. In addition, increasing concrete class seems not a suitable solution. The selected RC structure with equal tension and compression reinforcement ratio, Model-II, showed nearly equal response at C20 and C25 concrete class level. 1.5 times higher tension reinforcement ratio showed expected high performance with $\mathrm{C} 25$ concrete class. The basic variable that effects the performance of the five storey generic building is the tension reinforcement. However, there is an exceptional result was obtained from the Model-I with $25 \mathrm{MPa}$ concrete compressive strength. The reason of this is the brittle behaviour of the beam. Increasing concrete compressive strength is resulted early crush of the concrete and allowed to produce plastic hinge along the beam. This behaviour resulted low lateral bearing capacity.

Interstory drift ratio was plotted in Figure 7 for 5 story RC structures obtained with analysis result of eleven seismic records. Drift limits were determined based on the TEC2007 and TBEC2018 damage limits. During the calculation of damage limits according to TBEC2018, ZD soil type was selected.

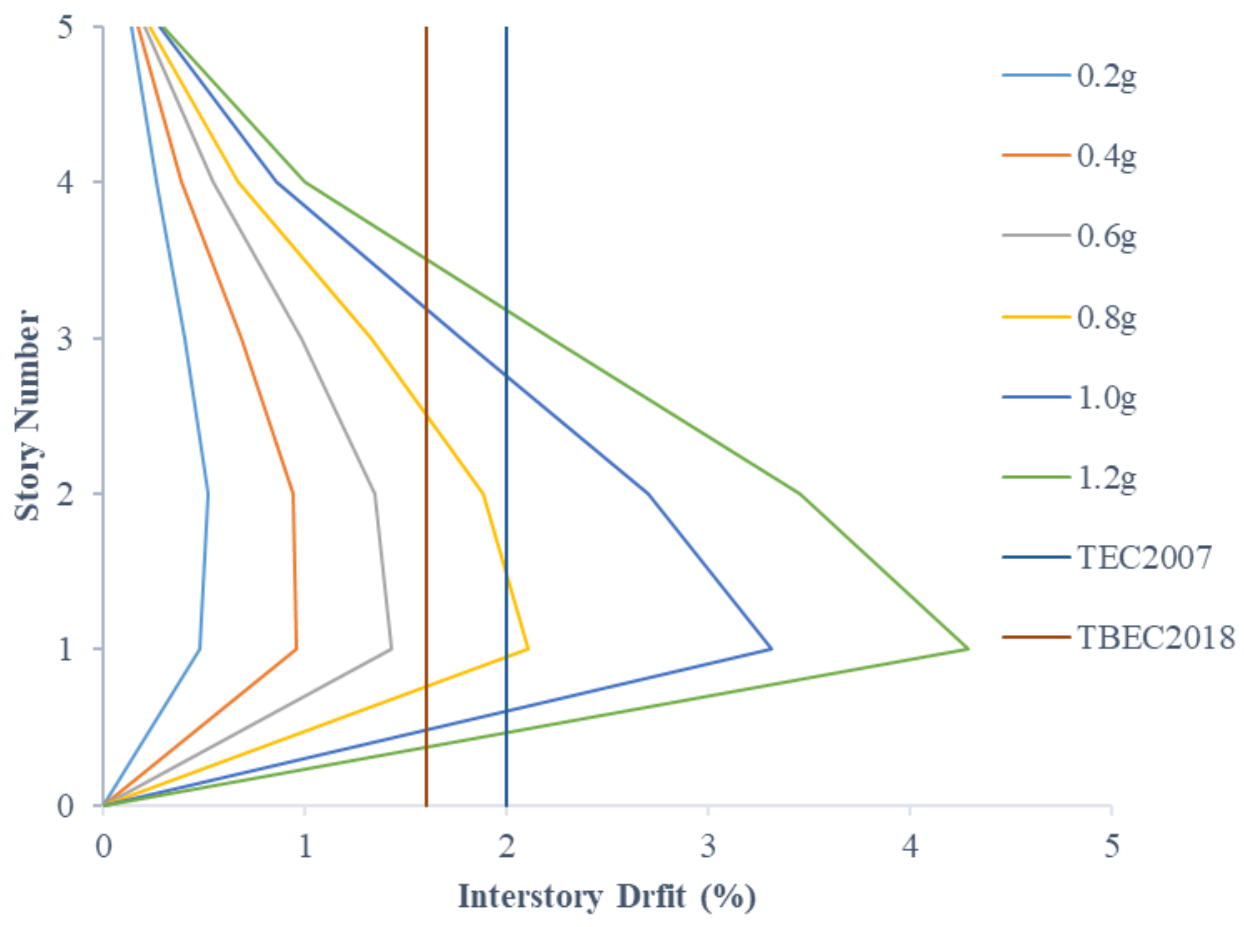

Figure 7:

Story number-Interstory Drift (\%) for 5 story structure

The same earthquake records were used also 7 story generic RC structure to see performance of the structure with changing tension reinforcement ratios. The IDA results for 7 story RC structure were plotted in Figure 8 for $20 \mathrm{MPa}$ concrete class.

According to IDA results, lateral base shear capacity of the reinforced concrete generic structure increased with increasing tension reinforcement ratio. There are two exceptional results were observed at Adana and Bingöl earthquakes. These exceptional results present that equal reinforcement 
ratio (Model-II) showed worse performance than Model-I. Rest of the results showed that increasing rebar ratio provides better performance than less reinforcement ratio. The highest displacement values were obtained from Erzincan earthquake record. Moreover, the peak base shear was also obtained from Erzincan earthquake. The IDA results for 7 story reinforced concrete structure was plotted in Figure 9 for $25 \mathrm{MPa}$ concrete class.

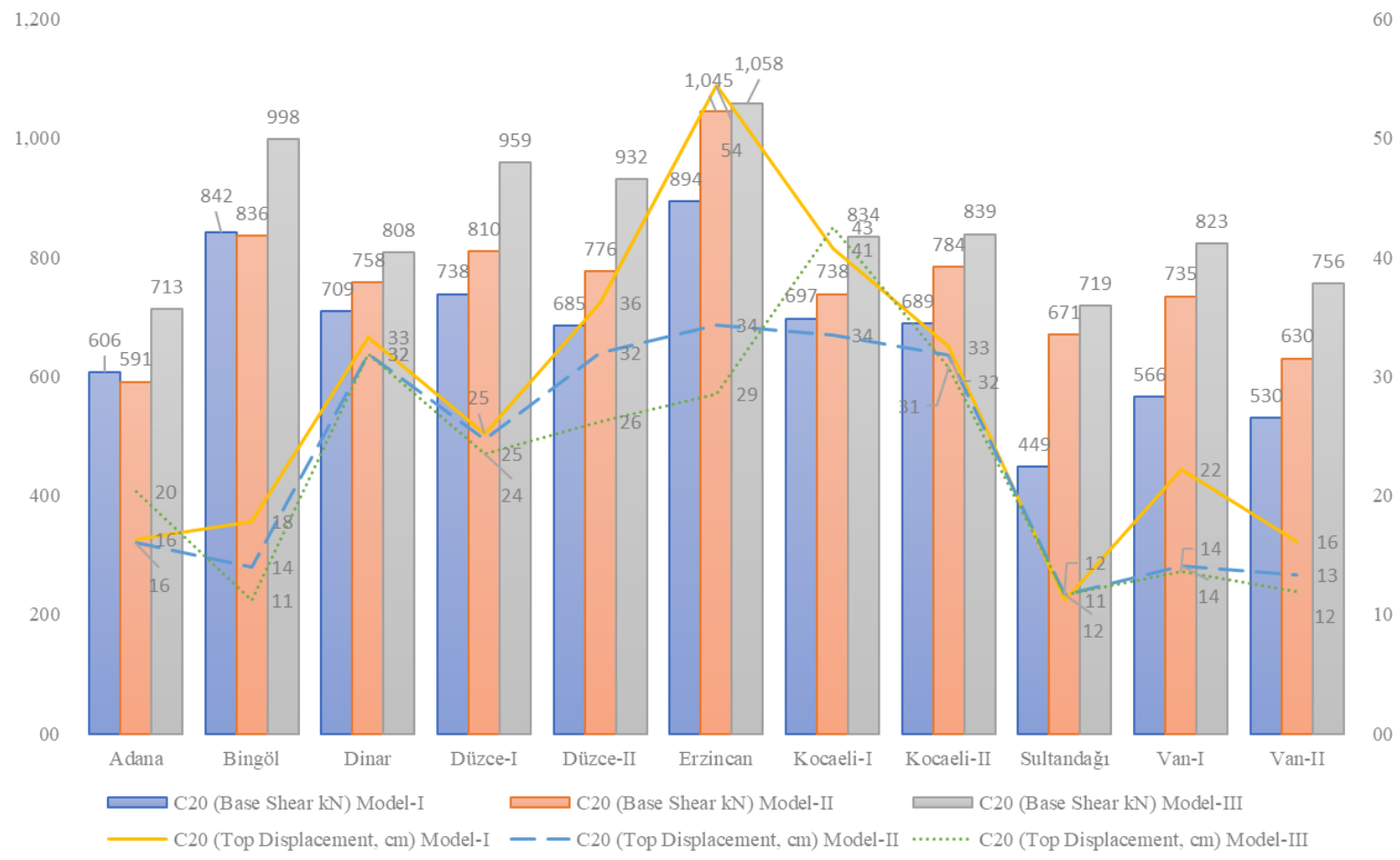

Figure 8:

Seismic response of the seven-story generic numeric model with C20 concrete 


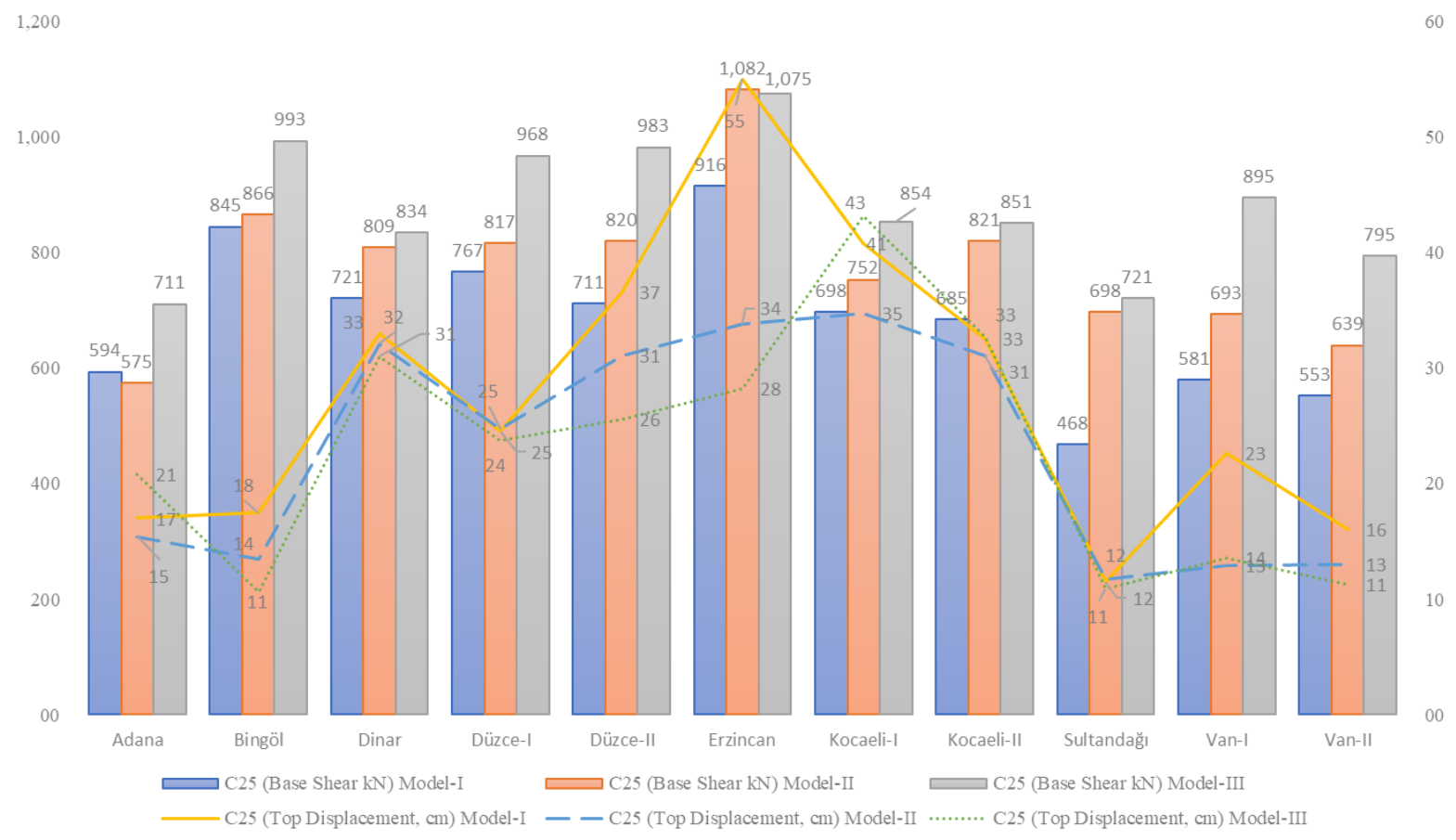

Figure 9:

Seismic response of the seven-story generic numeric model with C25 concrete

The IDA results showed that generally lateral base shear capacity was increased with increasing tension reinforcement ratio. However, two exceptional results were obtained from Adana and Erzincan earthquake records. The rest of the results similarly showed an increasing trend with the increasing tension reinforcement ratio. 
Uludağ University Journal of The Faculty of Engineering, Vol. 26, No.1, 2021

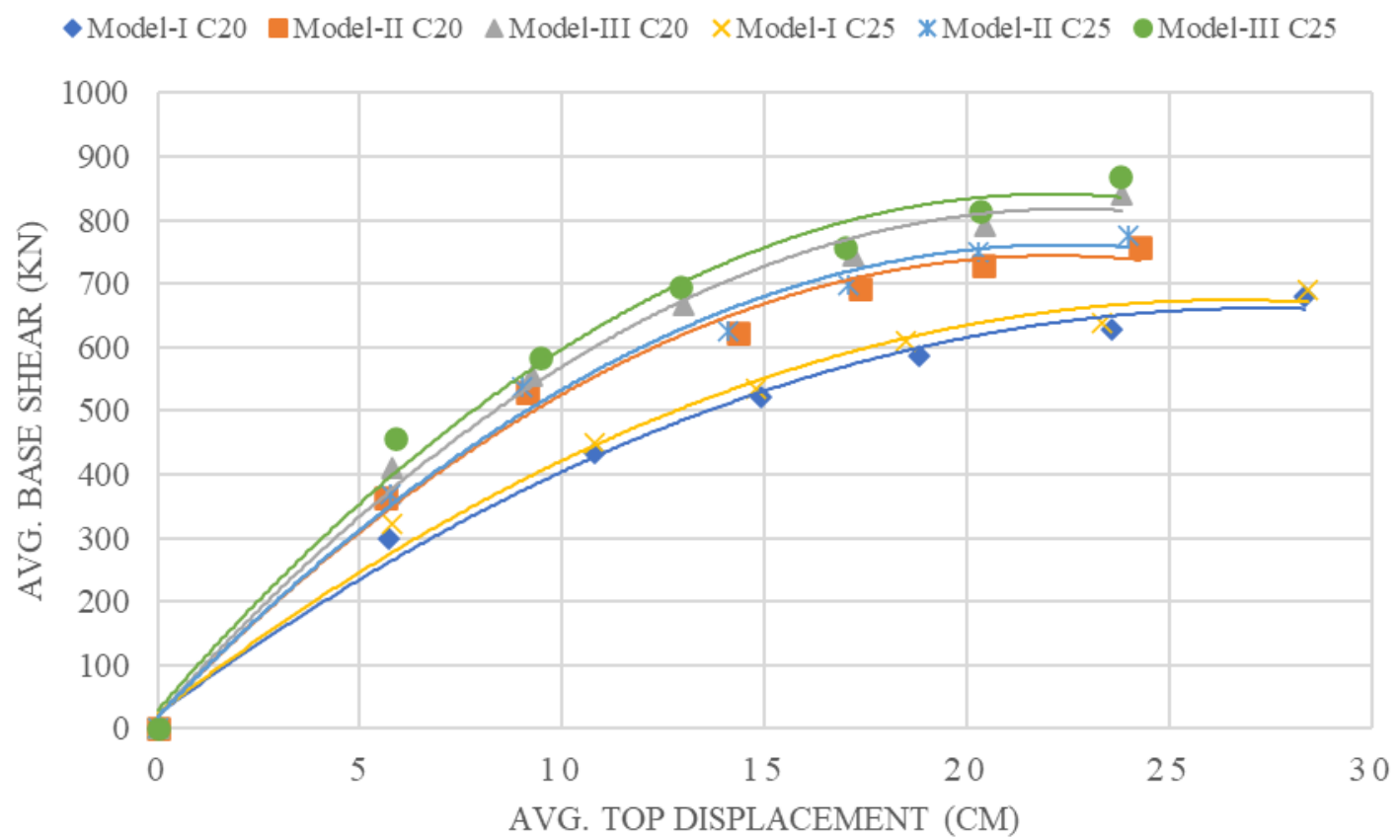

Figure 10:

Seismic response of the seven-story generic numeric model with C20 and C25 concrete

The visual performance of Figure 9 represents that the seismic response of Model-II is far better than Model-I. However, increasing tension reinforcement after the equal ratio of tension and compression reinforcement ratio, provide almost the same result. Lower tension reinforcement ratio that represented with Model-I showed rather ductile behavior than other models for seven story structural system. The increase in concrete compressive strength provides a considerable increase even if the tensile reinforcement remains constant. Concrete quality control is important.

Interstory drift ratio versus story number graph was plotted in Figure 11 below. Increasing tension reinforcement increases the bearing capacity for all models. However, ductility of the frame was decreased. Increasing concrete compressive strength increases the lateral bearing capacity slightly for all models. 


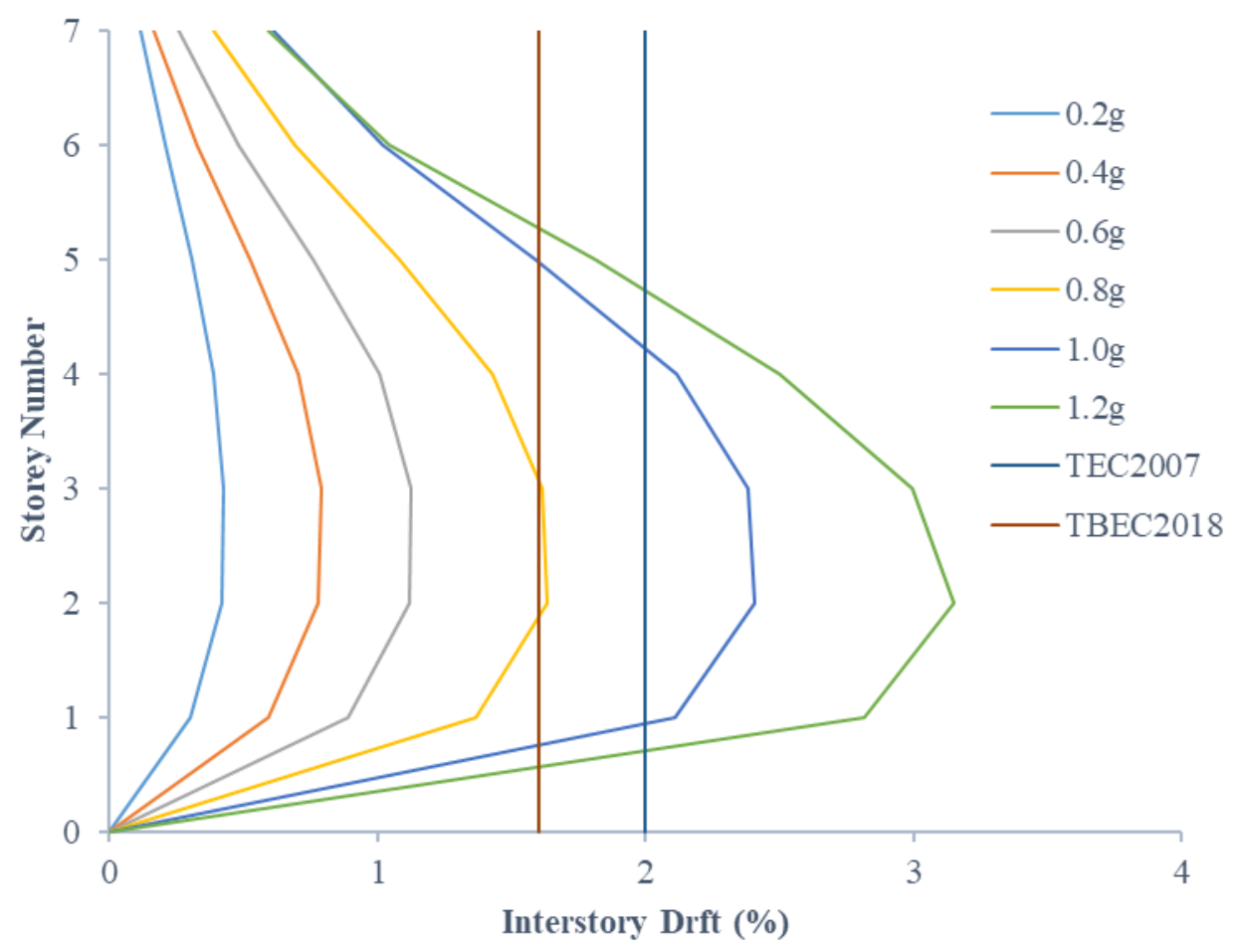

Figure 11:

Story number-Interstory Drift (\%) for seven story model

In both Figure 7 and Figure 11, concrete class and tension reinforcement ratio has not been able to present due to similar values in terms of drift.

\section{CONCLUSION}

This paper aims to investigate global response of mid-rise RC structures under dynamic analysis. For this purpose, eleven earthquake records were selected and used for IDA. Two different concrete class were used, and three different tension reinforcement ratios used for 5 story and 7 story RC structures with the same plan view. According to IDA results, following results were listed,

- To assess global response of a reinforced concrete structure, IDA analysis presents more option to evaluate results.

- According to IDA results, lateral base shear demand can be increased by increasing tension reinforcement ratio.

- Double tension reinforcement ratio showed a better performance than equal tension reinforcement for a general aspect.

- Increasing concrete class is a solution related to complete structural system to increase lateral base shear demand of a reinforced concrete structure. However, increasing tension reinforcement is a member-based solution to increase the performance of the structure.

- Increasing concrete compressive strength resulted in low bearing capacity due to early crushing of concrete before than rebar yield at five story model. 
- Increasing concrete compressive strength is provided a continuous increase in lateral bearing capacity at seven story model.

- Obtained maximum top displacement depends on the earthquake PGA. Top displacement presents an increasing tendency as shown in the figures.

- The investigated reinforced concrete structure should be exposed to low amplitude and low PGA earthquake like Sultandağ displacement capacity with a certain range.

\section{CONFLICT OF INTEREST}

The authors declare that there is not any conflict of interest between the authors.

\section{AUTHOR CONTRIBUTION}

Onur Onat: Conceptualization, Investigation, Methodology, Numerical Analysis, Writing - review \& editing

Burak Yön: Conceptualization, Investigation, Methodology, Review \& editing

\section{REFERENCES}

1. Ashour, S. A. (2000). Effect of compressive strength and tensile reinforcement ratio on flexural behavior of high-strength concrete beams, Engineering structures, 22(5), 413-423. doi.org/10.1016/S0141-0296(98)00135-7

2. Duan, H. and Hueste, M. B. D. (2012). Seismic performance of a reinforced concrete frame building in China, Engineering Structures, 41, 77-89. doi.org/10.1016/j.engstruct.2012.03.030

3. Fantilli, A. P. Ferretti, D. Iori, I. and Vallini, P. (1999). Behaviour of R/C elements in bending and tension: the problem of minimum reinforcement ratio, European Structural Integrity Society, 99-125. doi.org/10.1016/S1566-1369(99)80063-6

4. Ghatte, H. F. (2019). Evaluation of reinforcing bars ratio effects on scc beam-column joint performance, Uludağ University Journal of The Faculty of Engineering, 24(3), 141-152. doi: 10.17482/uumfd. 587505

5. Jouneghani, H. G. and Haghollahi, A. (2020). Assessing the seismic behavior of steel moment frames equipped by elliptical brace through incremental dynamic analysis (IDA), Earthquake Engineering and Engineering Vibration, 19, 435-449. doi.org/10.1007/s11803-020-0572-z

6. Karabulut, A. (2011). TDY2007 Yönetmeliği ve FEMA 440 raporunda tanimlanan doğrusal olmayan analiz yöntemlerinin mevcut betonarme binalar için karşilaştirilmasi. İstanbul Teknik Üniversitesi, Yüksek Lisans Tezi. doi: N/A

7. Kordtabar, B. and Dehestani, M. (2020). Effect of corrosion in reinforced concrete frame components on pushover behavior and ductility of frame. Structural Concrete. doi:10.1002/suco.202000309

8. Kwon, O. S. and Kim, E. (2010). Case study: Analytical investigation on the failure of a twostory RC building damaged during the 2007 Pisco-Chincha earthquake, Engineering Structures, 32, 1876-1887. doi.org/10.1016/j.engstruct.2009.12.022 
Onat O., Yön B.: Incremental Dynamc. Analysis of Mid-Rise RC Buildings

9. Lee, T. and Pan, A. D. (2003). Estimating the relationship between tension reinforcement and ductility of reinforced concrete beam sections, Engineering Structures. 25(8), 1057-1067. doi.org/10.1016/S0141-0296(03)00048-8

10. Mander, J. B. Priestley. M. J. N. and Park, R. (1988). Theoretical stress-strain model for confined concrete, Journal of Structural Engineering (ASCE), 1804-1826. Doi: N/A

11. Martineau, M. O. Lopez, A. F. and Vielma, J. C. (2020). Effect of Earthquake Ground Motion Duration on the Seismic Response of a Low-Rise RC Building. Advances in Civil Engineering, 2020. doi.org/10.1155/2020/8891282

12. Mwafy, A. and Khalifa, S. (2017). Effect of vertical structural irregularity on seismic design of tall buildings. The Structural Design of Tall and Special Buildings, 26(18), e1399. doi.org/10.1002/tal.1399

13. Nazari, Y. R. and Saatcioglu, M. (2017). Seismic vulnerability assessment of concrete shear wall buildings through fragility analysis. Journal of Building Engineering, 12, 202-209. doi.org/10.1016/j.jobe.2017.06.006

14. Onat, O. (2019). Experimental damage evaluation of prototype infill wall based on forced vibration test. Adv Concr Constr, 8(2), 77-90. doi.org/10.12989/acc.2019.8.2.077

15. Onat, O. Correia, A. A. Lourenço, P. B. and Koçak, A. (2018). Assessment of the combined inplane and out-of-plane behavior of brick infill walls within reinforced concrete frames under seismic loading, Earthquake Engineering \& Structural Dynamics, 47(14), 2821-2839. doi.org/10.1002/eqe.3111

16. Onat, O. Lourenco, P. B. and Kocak, A. (2015). Experimental and numerical analysis of RC structure with two leaf cavity wall subjected to shake table, Structural Engineering \& Mechanics, 55(5), 1037-1055. doi.org/10.12989/sem.2015.55.5.1037

17. Onat, O. Lourenco, P. B. and Kocak, A. (2016). Nonlinear analysis of RC structure with massive infill wall exposed to shake table, Earthquake and Structures, 10(4), 811-828. doi.org/10.12989/eas.2016.10.4.811

18. Onat, O. Lourenço, P. B. and Koçak, A. (2017). Structural model calibration of RC structure with two-leaf cavity brick infill wall by deterministic approach, Građevinar, 69(03), 171-181. doi.org/10.14256/JCE.1225.2015

19. Onat, O. Yön, B. and Calayır, Y. (2018). Seismic assessment of existing RC buildings before and after shear-wall retrofitting, Građevinar, 70(08), 703-712. doi.org/10.14256/JCE.2068.2017

20. Onat, O., \& Yön, B. (2019). Elimination of a measurement problem: A robust prediction model for missing eigenvector value to assess earthquake induced out-of-plane failure of infill wall. Measurement, 144, 88-104. doi.org/10.1016/j.measurement.2019.05.001

21. Rizwan, M. Ahmad, N. and Khan, A. N. (2020, November). Seismic performance assessment of reinforced concrete moment resisting frame with low strength concrete. In Structures. Elsevier. doi.org/10.1016/j.istruc.2020.10.038

22. Rodrigues, H. (2012). Biaxial seismic behaviour of reinforced concrete columns, PhD Thesis, Universidade de Aveiro, Portugal. doi: N/A 
23. SeismoStruct v7- A computer program developed for the accurate analytical assessment of structures, subjected to earthquake strong motion. Available online: www.seismosoft.com (May $8,2019)$

24. Theriault, M. and Benmokrane, B. (1998). Effects of FRP reinforcement ratio and concrete strength on flexural behavior of concrete beams, Journal of composites for construction, 2(1), 7 16. doi.org/10.1061/(ASCE)1090-0268(1998)2:1(7)

25. Turkey Ministry of Environment and Urbanization (2018). Turkish Building Earthquake Code, Ankara, Turkey.

26. Vamvatsikos, D. and Cornell, C. A. (2002). Incremental dynamic analysis, Earthquake Engineering \& Structural Dynamics, 31(3), 491-514. doi.org/10.1002/eqe.141

27. Vamvatsikos, D. and Cornell, C. A. (2004). Applied Incremental Dynamic Analysis, Earthquake Spectra, 20(2), 523-553. doi.org/10.1193/1.1737737

28. Wu, C. Pan, Z. Jin, C. and Meng, S. (2020). Evaluation of deformation-based seismic performance of RECC frames based on IDA method. Engineering Structures, 211, 110499. doi.org/10.1016/j.engstruct.2020.110499

29. Yön, B. (2016). An evaluation of the seismic response of symmetric steel space buildings, Steel and Composite Structures, 20(2), 399-412. doi.org/10.12989/scs.2016.20.2.399

30. Yön, B. (2020). Seismic vulnerability assessment of RC buildings according to the 2007 and 2018 Turkish seismic codes. Earthquakes and Structures, 18(6), 709-718. doi: 10.12989/eas.2020.18.6.709

31. Yön, B. and Calayır, Y. (2015). The soil effect on the seismic behaviour of reinforced concrete buildings. Earthquakes and Structures, 8(1), 133-152. doi.org/10.12989/eas.2015.8.1.133

32. Yön, B. Öncü, M. E. and Calayır, Y. (2014). Effects of seismic zones and site conditions on response of RC buildings, Gradevinar, 67(6), 585-596. doi:10.14256/JCE.1192.2014 
